\title{
The Adoption of Biometric Fingerprint Timekeeping Technology in the Ghanaian Business Community - Effectiveness and Impact
}

\author{
James T. Ami-Narh \\ University of Professional \\ Studies, Accra \\ Department of IT Studies
}

\author{
Lawrence K. Aziale \\ University of Professional \\ Studies, Accra \\ Department of IT Studies
}

\author{
Albert A. Akanferi \\ University of Professional \\ Studies, Accra \\ Department of IT Studies
}

\begin{abstract}
Timekeeping mechanisms are relevant to organisational productivity. Moreover, biometric timekeeping methods are more robust and provide access to enhanced systems of employee motivation and monitoring. This study sought to investigate the impact of the adoption and usage of biometric time and attendance management systems among the Ghanaian business community in the Greater Accra Metropolis. The study involved a quantitative research, and its population was the entire registered membership of Association of Ghana Industries in the Greater Accra Region of Ghana made up of 845 members. A sample size of 200 was chosen. This represented a sample size of $23.6 \%$ of the total population. Primary and secondary data were used, and selfadministered questionnaire was the instrument used in primary data collection. Statistical tools used for data analysis were goodness-of-fit (Chi-square) test, $2 \times 2$ contingency table and Friedman (K-related samples) test. Results of the study indicated that biometric timekeeping technologies are more secured than traditional timekeeping methods. Moreover, the use of biometric timekeeping technologies has better effect on organization labour cost as compared with traditional methods. Also, investment in biometric timekeeping technologies is worth the cost, and biometric hardware technologies are not susceptible to frequent breakdown as compared to traditional methods. The study concludes that biometric timekeeping technology is more useful and applicable within the business community in Ghana. It is recommended therefore that its adoption should be encouraged in the various organisational setups in the economy.
\end{abstract}

\section{General Terms}

Fingerprint Recognition, Time Management, Biometric.

\section{Keywords}

Timekeeping, Biometric, Fingerprint, Timekeeping Methods, Technology Acceptance.

\section{INTRODUCTION}

Time keeping can be a daunting task for employers. The process of capturing time actually worked by employees can be difficult, making accurate payment of wages a challenge. In recent times, however, computer technology has come out with new methods to address the numerous challenges associated with time and attendance management at work places. According to [1], "Advances in software and data collection devices help employers track hours worked, reduce calculation errors and improve payroll processing time. Automated timekeeping systems provide employers with tools that ease the burdensome task of manually recording time and applying other wage and hour rules, such as those regarding overtime, breaks and meals, on a per-employee basis."
Time and attendance management is the act or process of determining the time an employee reported to work. In time past, time and attendance management was carried out using traditional management approaches such as Timesheets, Time Cards, and Time Clocks which were associated with numerous challenges such as impersonation, collusions and inaccurate recordings of employees reporting time to work. A search for solutions to address these challenges led to the advent of computer-based time and attendance management technologies such as biometric time and attendance management systems. Biometric time and attendance system has been one of the most successful applications of biometric technology with a primary advantage of it avoiding "buddypunching" which was a major loophole of the traditional time and attendance management systems[2].

Time keeping is seen by many business practitioners as a key factor to improve productivity, labour cost management, reduction of cognitive dissonance among workforces and above all leads to efficient use of human resource at the workplace. As posited by Aberdeen Group, a [3] in their benchmark report globally, time and attendance systems have become the very cornerstone for laying a foundation of effective workforce management systems. Their benchmark report is a compilation of surveys and interviews from over 300 organizations globally, and highlights how Best-in-Class performers are maximizing the value of their time and attendance management systems to improve employee satisfaction, increase revenue, and decrease labour costs.

Further empirical studies from the USA and United Kingdom show that time and attendance management are closely negatively related to labour cost. As [4], a global provider of IT advisory and research services, found that $74 \%$ of organizations experience payroll losses that are directly related to 'buddy punching'. Nucleus Research found that organizations can save $2.2 \%$ of gross payroll annually on average by eliminating 'buddy punching' through the use of innovative biometric technology.

In Asian countries, the use of biometric technologies goes beyond timekeeping measure as posited by[5]:

Hong Kong contractors are increasingly turning to biometric technology to help them quickly give access to authorized workers and accurately deny entry to people who should not be on site. With biometric technology, a worker's permit and safety training records, along with expiration dates, can be entered into a database that not only verifies an employee's identity, but instantly checks to see if that employee is authorized to be there. For many Hong Kong construction companies, biometric Hand-Readers are the technology of choice. 
A cursory look around the Ghanaian business environment reveals that timekeeping is one of the most neglected areas of business' operations, yet, one that can make or mar the fortune of any business entity.

\section{STATEMENT OF THE PROBLEM}

In today's corporate world, globalisation has forced every firm to be efficient and accurate in their processes through the principles of Information and Communication Technology (ICT) adoption. ICT is now so deeply rooted within organisation's infrastructure, making millions to depend on
$\mathbf{H}_{\mathbf{0 2}}$ : The use of biometric timekeeping technologies has the same effect on organization labour cost as compared with traditional methods.

$\mathbf{H}_{12}$ : The use of biometric timekeeping technologies has better effect on organization labour cost as compared with traditional methods.

$\mathrm{H}_{03}$ : Investment in biometric timekeeping technologies is not worth the cost.

$\mathbf{H}_{13}$ : Investment in biometric timekeeping technologies is

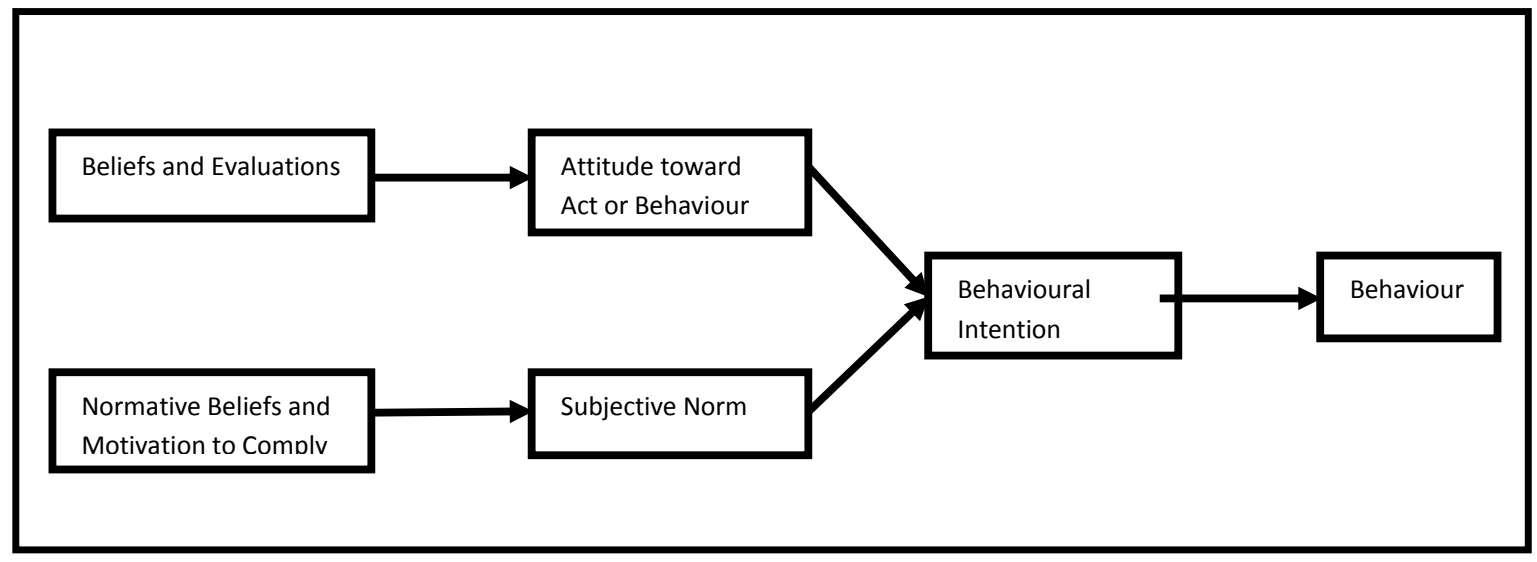

Figure 1: A framework of Theory of Reasoned Action (TRA), Fishbein \& Ajzen (1975)

them each day for tackling everyday tasks. Biometric time and attendance management system is one such ICT tools used every day at the workplace with its invaluable benefits.

In spite of these valuable benefits of ICT use in time and attendance management, a number of resistances have been recorded against ICT adoption in the work place. Research provides valuable insights into how and why employees may resist the adoption and use of information technologies (ITs) in the workplace.

A look however among the business community in Ghana reveals that the adoption of biometric time and attendance management systems is very low. This study therefore, seeks to investigate the effectiveness and impacts of the adoption of biometric time and attendance management systems in Ghana.

\section{OBJECTIVES OF THE STUDY}

This study sought to investigate the effectiveness and impact of the adoption and usage of biometric time and attendance management systems among the Ghanaian business community in the Greater Accra Metropolis.

\section{HYPOTHESES}

$\mathbf{H}_{\mathbf{0 1}}$ : Biometric timekeeping technologies are not more secured than traditional timekeeping methods.

$\mathbf{H}_{11}$ : Biometric timekeeping technologies are more secured than traditional timekeeping methods. worth the cost.

$\mathbf{H}_{04}$ : Biometric hardware technologies are susceptible to frequent breakdown just as the traditional methods.

$\mathbf{H}_{14}$ : Biometric hardware technologies are not susceptible to frequent breakdown as compared to traditional methods.

\section{LITERATUREREVIEW}

\subsection{Theoretical Framework}

Many theories underline the concept of technology adoption among various groups of people the world over. One of these theories is the technology acceptance model (TAM) propounded by Davis (1989 cited in [6]. This theory is based on the theory of reasoned action (TRA) (Fishbein \& Ajzen, 1975 cited in [7]) used widely in psychological studies. The TRA proposes that individual behaviour is driven by behavioural intention where behavioural intention is a function of an individual's attitude toward the behaviour and subjective norms surrounding the performance of the behaviour. In other words, it states that one's behaviour and the intent to behave is a function of one's attitude toward the behaviour and their perceptions about the behaviour. Therefore, behaviour is the function of both attitudes and beliefs. TRA is presented in Figure 1 above. 


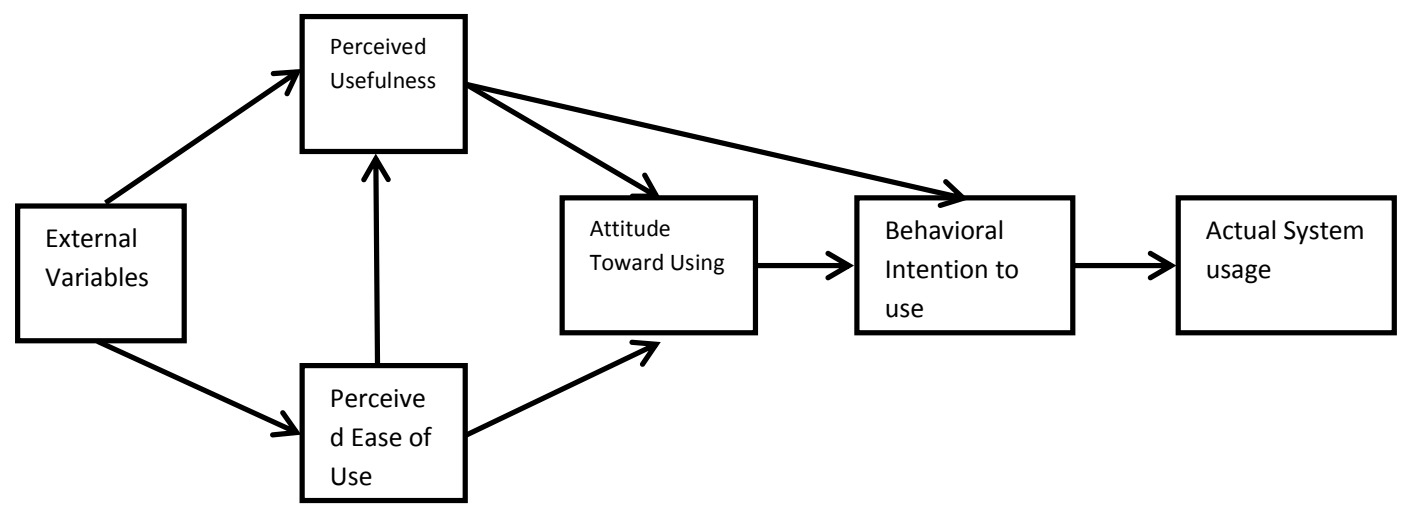

Figure 2: A framework of the theory of Technology Acceptance Model (TAM) by Davis (1989)

TAM proposes that perceived ease of use and perceived usefulness of technology are predictors of user attitude towards using a technology, subsequent behavioural intentions and actual usage. Perceived ease of use was also considered to influence perceived usefulness of technology. Figure 2 presents original version of TAM (Davis, 1989).

In TAM, perceived usefulness refers to the degree to which the user believes that using the technology will improve his or her work performance, while perceived ease of use refers to how effortless he or she perceives using the technology will be. Both are considered distinct factors influencing the user's attitude towards using the technology, however perceived ease of use is also hypothesized to influence perceived usefulness and attitude towards using the technology. The attitude towards using the technology determines the behavioural intention to use that technology.

This research study employs the model shown in Figure 3 below. It excludes the actual system use hence reducing the original TAM model. The study does not also include the external variables constructs since it is an exploratory study and also since there is no immediate intention to examine antecedents to perceived usefulness and perceived ease of use. posits that perceived ease of use and perceived usefulness predicts attitude toward use of a technology. Then, attitude toward use predicts the behavioral intention to use. Finally, intention predicts the actual use of that technology (Davis 1989, cited in Johnson [6]). A variety of applications have been used to validate the model (Ma and Liu 2004, cited in Johnson [6]). Some of the applications employed to study user acceptance include microcomputers, the World Wide Web, and decision support systems[6].

TAM has proven to be a theoretical model in helping to explain and predict user behavior of information technology[8]. TAM is considered an influential extension of theory of reasoned action (TRA), according to[9].

\section{Biometrics}

Physical and physiological-based biometrics pertains to any form of biometric that is found on and measured off the human body. Common physical characteristics of a person include fingerprints, iris and retinal analysis, facial recognition, sweat pore analysis, hand geometry, ear shape recognition, and DNA pattern[10, 11].

A key component of physical biometrics is that they hardly change over time. Some physical features such as fingerprint, eye, and DNA of a person are improbable to change

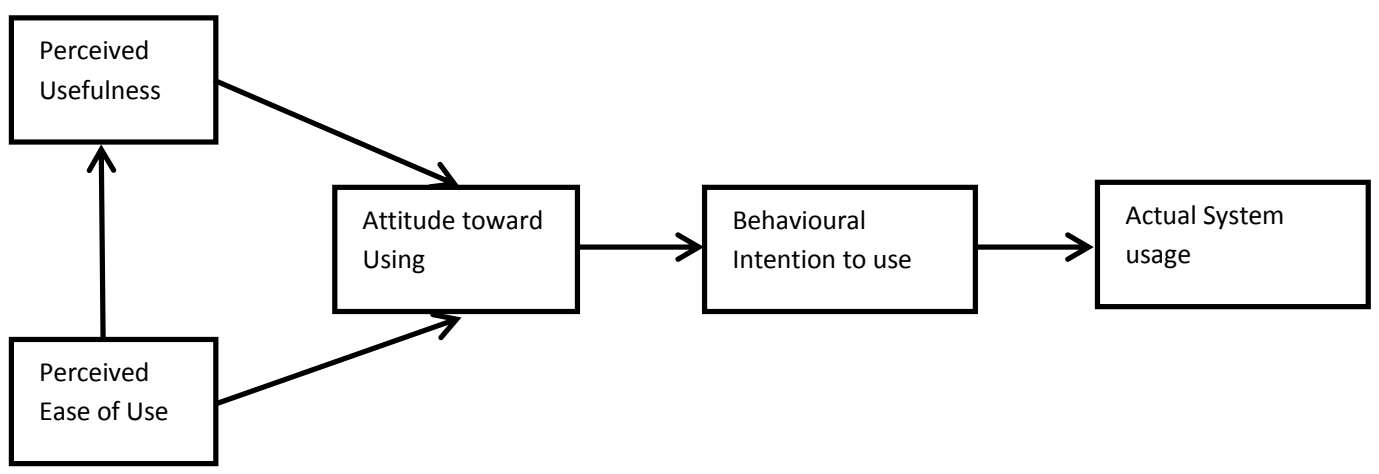

Figure 3: Revised Adopted TAM Model

\subsection{Theory Development}

The study employed the Technology Acceptance Model (TAM) propounded by Davis 1989 cited in Johnson [6]. TAM throughout their lifetimes except in highly unusual circumstances. Face recognition is the exception to invariability of biometric features. A person's face can 
change with age, use of glasses to help vision impairment, or changes in hair style or facial hair.

Behavioural-based biometrics encompass the habitual information of a person and include hand-written signature verification, keystroke analysis and gait analysis. Unlike Physical and physiological-based biometrics that remain relatively constant over time, behavioural-based biometrics can change in a very short period of time. Jain and Ross (2004) posit that the choice of a biometric system should be based on the following features:

- Individuality - indicates unique characteristics of persons

- Universality - which means that each person should have the characteristic

- Eternalness - characteristic of persons should not be changeable

- Measurability - individual data can be captured and measured.

Biometric fingerprint recognition systems increase accuracy, reflecting the actual working hours completed rather than those which staff would like to imagine that they have completed. It also provides data in a way which can be quickly and easily accessed in a variety of ways, by separate departments for different purposes [12, 13]. Biometrics fingerprint system offers:

- Fast real-time data capture and a non-repudiated audit trail

- Safe, secure, and accurate time management system

- Wider range of direct and indirect time, cost, and operational benefits than alternative time and attendance methods.

Studies conducted on the adoption of biometrics have highlighted several issues. [14] identified the limitation of the widespread use of biometric technology to the lack of a generic evaluation methodology that evaluates biometric systems taking into account: performance, users' acceptance and satisfaction, data quality and security aspects. [15] extended the conventional technology acceptance model (TAM) to investigate if user perceptions of biometrics security positively influenced their attitude and intention to use biometric banking. [16] proposed a model to reducing process-time for fingerprint identification system. [17]explored the factors that affect biometrics technology acceptance in hotels in Egyptian. [18]; [19]; [20]; [21]; [22]proposed methods for fingerprint matching. [23]; [24] researched fingerprint imaging. Fingerprint biometrics have also been identified as an effective way of identity management [25-27].Other researchers focus on the use biometrics in attendance management [12, 28, 29].

\section{METHODOLOGY}

\subsection{Data Collection Methods and Instruments}

The study made use of both primary and secondary data. The primary data was collected using questionnaires issued to the management and staff of all the 200 organisations that participated in the survey. While the secondary data comprised of literature and other organisational manuals which were gathered during study.

The title (Helvetica 18-point bold), authors' names (Helvetica 12-point) and affiliations (Helvetica 10-point) run across the full width of the page - one column wide. We also recommend e-mail address (Helvetica 12-point). See the top of this page for three addresses. If only one address is needed, center all address text. For two addresses, use two centered tabs, and so on. For three authors, you may have to improvise.

\subsection{Population and Sample Size}

The study population in this case is the entire registered membership of AGI in the Greater Accra Region of Ghana made up of 845 members. A sample size of 200 was chosen. This represents a sample size of $23.6 \%$ of the total population.

Table 1. Sample Size and Response Rate

\begin{tabular}{|l|l|l|l|}
\hline Organization & No. sent out & Valid No. Used & Percent \\
\hline Private & 200 & 174 & $87 \%$ \\
\hline
\end{tabular}

\subsection{Sample Size Selection and Sampling Design}

The simple random sampling method was used in selecting the sample size. The firms registered with the AGI in the Greater Accra Region were code and drawn from a box.

\subsection{Data Handling and Method of Analysis}

The data were analyzed using relational analysis and descriptive statistics by employing the Statistical Package for Social Sciences (SPSS version 16) and Microsoft Excel 2010.

\section{DATA ANALYSIS}

This section presents results on four tested null hypotheses. These hypotheses are tested at 0.05 level of significance using goodness-of-fit (Chi-square) test, $2 \times 2$ contingency table and Friedman (K-related samples) test. The following gives an outline of the null hypotheses tested in this section.

$\mathrm{H}_{01 \text { : }}$ Biometric timekeeping technologies are not more secured than traditional timekeeping methods.

$\mathrm{H}_{02}$ : The use of biometric timekeeping technologies has the same effect on organization labour cost as compared with traditional methods.

$\mathrm{H}_{03}$ : Investment in biometric timekeeping technologies is not worth the cost.

$\mathrm{H}_{04}$ : Biometric hardware technologies are susceptible to frequent breakdown just as the traditional methods.

Table 2. BFS more secure than Traditional Time-Keeping Methods

\begin{tabular}{|l|r|r|r|r|r|r|}
\hline & \multicolumn{1}{|c|}{ Observed N } & Expected N & \multicolumn{1}{c|}{ Residual } & \multicolumn{1}{c|}{ df } & \multicolumn{1}{c|}{ Chi-Square } & Asymp. Sig. \\
\hline Strongly Disagree & 3 & 34.6 & -31.6 & 4 & $215.642^{\mathrm{a}}$ & .000 \\
\hline Disagree & 5 & 34.6 & -29.6 & & & \\
\hline Neither & 7 & 34.6 & -27.6 & & & \\
\hline Agree & 100 & 34.6 & 65.4 & & & \\
\hline Strongly Agree & 58 & 34.6 & 23.4 & & & \\
\hline Total & 173 & & & & & \\
\hline
\end{tabular}


Table 3. BFS has better Effect on Organizational Labor Cost

\begin{tabular}{|l|r|r|r|r|r|c|}
\hline & \multicolumn{1}{|c|}{ Observed N } & Expected N & \multicolumn{1}{c|}{ Residual } & \multicolumn{1}{c|}{ df } & \multicolumn{1}{c|}{ Chi-Square } & Asymp. Sig. \\
\hline Disagree & 13 & 42.2 & -29.2 & 3 & $119.639^{\mathrm{a}}$ & .000 \\
\hline Neither & 24 & 42.2 & -18.2 & & & \\
\hline Agree & 103 & 42.2 & 60.8 & & & \\
\hline Strongly Agree & 29 & 42.2 & -13.2 & & & \\
\hline Total & 169 & & & & & \\
\hline
\end{tabular}

a. 0 cells $(.0 \%)$ have expected frequencies less than 5 . The minimum expected cell frequency is 42.3 .

Table 2 is a chi-square (goodness-of-fit) test. It tests the first hypothesis of the study which states that "biometric timekeeping technologies are not more secured than traditional timekeeping methods". From the table, 3 respondents strongly disagreed, whilst 5 respondents disagreed that BFS is more secure than traditional timekeeping methods. There were 100 and 58 respondents who agreed and strongly agreed respectively in this regard. These frequencies are significantly different at 0.05 level of significance, $X^{2}(174,4)=215.642, \mathrm{p}=.000$. The first null hypothesis of the study is therefore worth rejecting for the alternative hypothesis. It could therefore be concluded that biometric timekeeping technologies are more secured than traditional timekeeping methods.

Table 3 comes with results on the second null hypothesis. This hypothesis states that "the use of biometric timekeeping technologies has the same effect on organization labour cost as compared with traditional methods". Thirteen (13) respondents disagreed that BFS has better effect on labour cost. On the other hand, 103 respondents agreed whilst 29 strongly agreed. There were 24 respondents who neither agreed nor disagreed. The chi-square statistic indicates that the number of respondents who agreed is significantly higher than those who disagreed, $X^{2}(169,3)=119.639, p=.000$. This means that the null hypothesis is more likely to be untrue, and it may be concluded that the use of biometric timekeeping technologies has better effect on organization labour cost as compared with traditional methods. It must be noted however that total Observed $\mathrm{N}$ in Table 3 is less than what is in Table 2 due to non-responses or missing items.

Table 4 strengthens conclusion made against the third null hypothesis in Table 3. In this case, 97 and 51 respondents agreed and strongly agreed respectively that BFS saves cost for organization over traditional method. One (1) and 3 respondents respectively strongly disagreed and disagreed in this regard. The chi-square test indicates that there is a significant difference in the frequencies, $X^{2}(169,5)=$ $266.870, p=.000$. So Table 4 also provides sufficient evidence against the second null hypothesis. Findings in Tables 3 and 4 collectively indicates that the use of biometric timekeeping technologies has better effect on organization labour cost as compared with traditional methods.

Table 5 is associated with the test of the third null hypotheses. It tests the hypothesis that investment in biometric timekeeping technologies is not worth the cost. In Table 5, 89 and 40 respondents agreed and strongly agreed respectively that BFS provide value for money. On the other hand, 3 and 8 respondents strongly disagreed and disagreed respectively that BFS provide value for money in the organization. There is a significant difference in the frequencies associated with Table $4, X^{2}(167,4)=142.072, p=.000$. There is therefore ample evidence that BFS provide value for money for the organization. The third null hypothesis may therefore be rejected. The conclusion is that investment in biometric timekeeping technologies is worth the cost.

Table 6 is a cross tabulation of "BFS provides value for money" and "BFS saves cost". It is a precursor for identifying the possible relationship between "BFS provides value for money" and "BFS saves cost". Evidently, nearly equal proportions of respondents agreed and disagreed for "BFS provides value for money" and "BFS saves cost". This is likely to resonate in a relationship between the two variables. Table 7 confirms any possible relationship between "BFS provides value for money" and "BFS saves cost".

Table 4. BFS Saves Cost for Organization over Traditional TMS

\begin{tabular}{|l|c|c|c|c|c|c|}
\hline & Observed N & $\begin{array}{c}\text { Expected } \\
\mathrm{N}\end{array}$ & Residual & df & $\begin{array}{c}\text { Chi- } \\
\text { Square }\end{array}$ & $\begin{array}{c}\text { Asymp. } \\
\text { Sig. }\end{array}$ \\
\hline Strongly Disagree & 1 & 28.2 & -27.2 & 5 & $266.870^{\mathrm{a}}$ & .000 \\
\hline Disagree & 3 & 28.2 & -25.2 & & & \\
\hline Neither & 16 & 28.2 & -12.2 & & & \\
\hline Agree & 97 & 28.2 & 68.8 & & & \\
\hline Strongly Agree & 51 & 28.2 & 22.8 & & & \\
\hline Missing & 1 & 28.2 & -27.2 & & & \\
\hline Total & 169 & & & & & \\
\hline
\end{tabular}

a. 0 cells $(.0 \%)$ have expected frequencies less than 5. The minimum expected cell frequency is 28.2.

Table 5.BFS provide value for Money for Organization

\begin{tabular}{|l|c|c|c|c|c|c|}
\hline & Observed N & Expected N & Residual & df & Chi-Square & $\begin{array}{c}\text { Asymp. } \\
\text { Sig. }\end{array}$ \\
\hline Strongly Disagree & 3 & 33.4 & -30.4 & 4 & $142.072^{\mathrm{a}}$ & .000 \\
\hline Disagree & 8 & 33.4 & -25.4 & & & \\
\hline Neither & 27 & 33.4 & -6.4 & & & \\
\hline Agree & 89 & 33.4 & 55.6 & & & \\
\hline Strongly Agree & 40 & 33.4 & 6.6 & & & \\
\hline Total & 167 & & & & & \\
\hline
\end{tabular}

a. 0 cells $(.0 \%)$ have expected frequencies less than 5 . The minimum expected cell frequency is 33.4. 
Table 6.BFS provide value for money * BFS have cost savings over TMS Cross tabulation

\begin{tabular}{|c|c|c|c|c|c|c|}
\hline & \multicolumn{4}{|c|}{ BFS have cost savings over TMS } & \multirow{2}{*}{ Total } \\
\hline & & Disagree & Neither & Agree & Strongly Agree & \\
\hline \multirow{5}{*}{$\begin{array}{l}\text { BFS provide } \\
\text { value for } \\
\text { money }\end{array}$} & Strongly Disagree & 1 & 1 & 1 & 0 & 3 \\
\hline & Disagree & 3 & 2 & 2 & 1 & 8 \\
\hline & Neither & 3 & 10 & 11 & 3 & 27 \\
\hline & Agree & 3 & 11 & 66 & 6 & 86 \\
\hline & Strongly Agree & 1 & 0 & 20 & 19 & 40 \\
\hline Total & & 11 & 24 & 100 & 29 & 164 \\
\hline
\end{tabular}

Table 7 expresses the relationship between "BFS provides value for money" and "BFS saves cost". It comes with two measures of relationship, the Pearson Chi-Square and Kendall's tau-b. Pearson Chi-Square is significant at 0.05 level of significant, $\mathrm{p}=.000$, likewise Kendall's tau-b correlation coefficient, $r(164)=0.451, p=.000$.

Table 7. Relationship Measures

\begin{tabular}{|l|c|c|c|}
\hline Relationship Measure & Value & df & p-value \\
\hline Pearson Chi-Square & 69.444 & 12 & .000 \\
\hline Kendall's tau-b & 0.451 & & .000 \\
\hline N of Valid Cases & 164 & & \\
\hline
\end{tabular}

There is therefore adequate and ample evidence that "BFS provides value for money" and "BFS saves cost" are related.
Thus the ability of BFS to have cost saving over traditional methods enhances its ability to provide value for money within the organization.

Table 8 is associated with the test of the fourth null hypothesis. The fourth null hypothesis states that "biometric hardware technologies are susceptible to frequent break down just as the traditional methods". In this regard, 117 respondents agreed, whereas 22 strongly agreed. Relatively lower frequencies of 2 and 7 respondents respectively strongly disagreed and disagreed that BFS are not susceptible to frequent breakdown. Furthermore, the differences in frequencies are statistically significant at 0.05 level of significance, $X^{2}(168,4)=267.298, p=.000$. The gives rise to the need to reject the fourth null hypothesis. It could therefore be concluded that biometric hardware technologies are not susceptible to frequent break down just as the traditional methods.

Table 8. BFS are not Susceptible to Frequent Breakdowns

\begin{tabular}{|l|c|c|c|c|c|c|}
\hline & Observed N & Expected N & Residual & df & Chi-Square & Asymp. Sig. \\
\hline Strongly Disagree & 2 & 33.6 & -31.6 & 4 & $267.298^{\mathrm{a}}$ & .000 \\
\hline Disagree & 7 & 33.6 & -26.6 & & & \\
\hline Neither & 20 & 33.6 & -13.6 & & & \\
\hline Agree & 117 & 33.6 & 83.4 & & & \\
\hline Strongly Agree & 22 & 33.6 & -11.6 & & & \\
\hline Total & 168 & & & & & \\
\hline
\end{tabular}

a. $\quad 0$ cells $(.0 \%)$ have expected frequencies less than 5. The minimum expected cell frequency is 33.6.

Table 9 Biometric Timekeeping Technologies are Proven

\begin{tabular}{|l|c|c|c|c|c|c|}
\hline & Observed N & Expected N & Residual & df & Chi-Square & Asymp. Sig. \\
\hline Strongly Disagree & 1 & 34.2 & -33.2 & 4 & $280.667^{\mathrm{a}}$ & .000 \\
\hline Disagree & 3 & 34.2 & -31.2 & & & \\
\hline Neither & 12 & 34.2 & -22.2 & & & \\
\hline Agree & 118 & 34.2 & 83.8 & & & \\
\hline Strongly Agree & 37 & 34.2 & 2.8 & & & \\
\hline Total & 171 & & & & & \\
\hline
\end{tabular}

a. $\quad 0$ cells $(.0 \%)$ have expected frequencies less than 5 . The minimum expected cell frequency is 34.2 .

Table 9 unfolds findings that would tend to support conclusion against the fourth null hypothesis under Table 8. In Table 9, a majority of respondents agreed that biometric timekeeping technologies are proven.

Also, 37 respondents strongly agreed in this regard, whereas only 1 and 3 respondents strongly disagreed and disagreed respectively. There is a significant difference between these frequencies at 0.05 level of significance, $X^{2}(171,4)=$ $280.667, p=.000$. Consequently, there is sufficient evidence to the fact that biometric timekeeping technologies are proven, and this buttresses evidence against the fourth null hypothesis.

Table 10 shows descriptive statistics associated with variables of the four null hypotheses. Findings in this table are relevant for depicting the relative magnitude of all the variables associated with the four null hypotheses. With this table, the weight of respondents' agreement to each variable can be seen. Table 10 indicates that "BFS secured than traditional TAM systems" has the highest weight of agreement from respondents $(\mathrm{M}=4.21, \mathrm{SD}=0.801)$, followed by "Biometric timekeeping use proven technologies" $(\mathrm{M}=4.09, \mathrm{SD}=$ $0.656)$, "BFS provide value for money" $(\mathrm{M}=3.92$, $\mathrm{SD}=$ $0.869)$, "BFS technologies are reliable" $(\mathrm{M}=3.91, \mathrm{SD}=$ $0.676)$ and "BFS has cost savings over TMS" $(\mathrm{M}=3.88, \mathrm{SD}$ $=0.773)$. At a glance, the variables have unequal means. Table 11 shows if the difference in means is significant statistically.

Table 11 comes with a Friedman test. It identifies whether means or weights of agreement of respondents on the five variables in Table 10 are the same. The table indicates a significant difference between these means at 0.05 level of 
significance, $X^{2}(154,4)=38.176, p=.000$. Thus relative to the other four variables, there was a higher proportion of respondents who agreed that BFS is secured than traditional TAM systems. The five variables can therefore be arranged in order of decreasing weight in terms respondents agreement. This is given by: "BFS secured than traditional TAM systems" followed by "Biometric timekeeping use proven technologies", "BFS provide value for money", "BFS technologies are reliable" and "BFS has cost savings over TMS".

Table 12 provides a summary of results of the four null hypotheses tested. The table indicates that all four null hypotheses are rejected at 0.05 level of significance. Consequently, the corresponding alternative hypotheses of the hypotheses make up the conclusion of the study.

Table 10.Descriptive Statistics

\begin{tabular}{|l|c|c|c|}
\hline Variable & $\mathrm{N}$ & Mean & $\begin{array}{c}\text { Std. } \\
\text { Deviation }\end{array}$ \\
\hline $\begin{array}{l}\text { BFS secured than } \\
\text { traditional TAM } \\
\text { systems }\end{array}$ & 156 & 4.21 & 0.801 \\
\hline $\begin{array}{l}\text { BFS technologies are } \\
\text { reliable }\end{array}$ & 156 & 3.91 & 0.676 \\
\hline
\end{tabular}

\begin{tabular}{|l|c|c|c|}
$\begin{array}{l}\text { BFS provide value for } \\
\text { money }\end{array}$ & 156 & 3.92 & 0.869 \\
\hline $\begin{array}{l}\text { BFS have cost savings } \\
\text { over TMS }\end{array}$ & 156 & 3.88 & 0.773 \\
\hline $\begin{array}{l}\text { Biometric time } \\
\text { keeping use proven } \\
\text { technology }\end{array}$ & 156 & 4.09 & 0.656 \\
\hline
\end{tabular}

Table 11.Friedman Test

\begin{tabular}{|c|c|c|c|c|}
\hline & $\begin{array}{l}\text { Mean } \\
\text { Rank }\end{array}$ & $\mathrm{df}$ & $\begin{array}{c}\text { Chi- } \\
\text { Square }\end{array}$ & $\begin{array}{l}\text { Asymp. } \\
\text { Sig. }\end{array}$ \\
\hline $\begin{array}{l}\text { BFS secured than } \\
\text { traditional TAM } \\
\text { systems }\end{array}$ & 4.21 & 4 & 38.176 & .000 \\
\hline $\begin{array}{l}\text { BFS technologies } \\
\text { are reliable }\end{array}$ & 3.91 & & & \\
\hline $\begin{array}{l}\text { BFS provide value } \\
\text { for money }\end{array}$ & 3.92 & & & \\
\hline $\begin{array}{l}\text { BFS have cost } \\
\text { savings over TMS }\end{array}$ & 3.88 & & & \\
\hline $\begin{array}{l}\text { Biometric } \\
\text { timekeeping use } \\
\text { proven technology }\end{array}$ & 4.09 & & & \\
\hline
\end{tabular}

Table 12.Summary of Hypotheses Test

\begin{tabular}{|c|c|c|l|l|}
\hline Hypothesis \# & $\alpha$ & $P$-value & Decision & Conclusion \\
\hline 1 & 0.05 & .000 & Rejected & $\begin{array}{l}\text { Biometric timekeeping technologies are more secured than traditional } \\
\text { timekeeping methods }\end{array}$ \\
\hline 2 & 0.05 & .000 & Rejected & $\begin{array}{l}\text { The use of biometric timekeeping technologies has better effect on } \\
\text { organization labour cost as compared with traditional methods }\end{array}$ \\
\hline 3 & 0.05 & .000 & Rejected & Investment in biometric timekeeping technologies is worth the cost \\
\hline 4 & 0.05 & .000 & Rejected & $\begin{array}{l}\text { Biometric hardware technologies are not susceptible to frequent } \\
\text { breakdown as compared to traditional methods. }\end{array}$ \\
\hline
\end{tabular}

\section{DISCUSSION, CONCLUSION AND RECOMMENDATION}

According to findings of this study, biometric timekeeping technologies are more secured than traditional timekeeping methods. Technology Acceptance Theory (TAM) propounded by Davis (1989) points to the perceived ease of use and usefulness of technologies such as those associated with biometric timekeeping. In view of this, TAM resonates with the finding that biometric time keeping technologies are more secure relative to traditional methods, as usefulness and use of biometric timekeeping would be driven by how secure they are. On the other hand, [30] empirically buttressed this point. In agreement to the findings of [31] and [32] and the principles on which TAM is premised, the use of biometric timekeeping technologies has better effect on organization labour cost as compared with traditional methods. This means that the adoption and use of biometric timekeeping methods help management to minimise expenditure on labour. This relates to another finding that investment in biometric timekeeping technologies is worth the cost. One of the study's finding also justify TAM, and this has to do with the discovery that biometric hardware technologies are not susceptible to frequent breakdown as compared to traditional methods. This is supported empirically by [33] and [34].

Based on findings of this study, it could be concluded that biometric timekeeping technologies are more secured than traditional timekeeping methods. Secondly, the use of biometric timekeeping technologies has better effect on organization labour cost as compared with traditional methods. Investment in biometric timekeeping technologies is worth the cost. Last but not least, biometric hardware technologies are not susceptible to frequent breakdown as compared to traditional methods. In simple terms, biometric timekeeping technology could be useful and applicable within the organisational setup. As a result, it is recommended that its adoption and use is encouraged among Ghanaian firms or members of the Association of Ghana Industries (AGI).

\section{REFERENCES}

[1] Beyda, C.S. and V.S. Jefferiss, Well-Rounded Timekeeping. HRMagazine, 2011: p. 75-77.

[2] Josphineleela, R. and M. Ramakrishnan, An Efficient Automatic Attendance System Using Fingerprint Reconstruction Technique. International Journal of Computer Science and Information Security (IJCSIS), 2012. 10(3).

[3] Aberdeen Group, Evolving Time and Attendance: Foundation for Workforce Management Improvements, 2008.

[4] Nucleus Research ROI Evaluation Report:: KRONOS Workforce Timekeeper. 2006. 
[5] Yuen, T., Hong Kong Construction Sites Use Hundreds of Biometric HandReaders 2013.

[6] Johnson, A.M. The Technology Acceptance Model and the Decision to Invest in Information Security. in Proceedings of the 2005 Southern Association of Information Systems Conference. 2005.

[7] Lule, I., T.K. Omwansa, and T.M. Waema, Application of Technology Acceptance Model (TAM) in M-Banking Adoption in Kenya. International Journal of Computing and ICT Research, 2012. 6(1): p. 31-43.

[8] Legris, P., J. Inghamb, and P. Collerettec, Why do people use information technology? A critical review of the technology acceptance model. Information \& Management, 2003. 40(2003): p. 191-204.

[9] Ajzen, I. and M. Fishbein, Understanding attitudes and predicting social behavior. 1980, Englewood Cliffs, NJ: Prentice-Hall.

[10] Jain, A.K., P.J. Flynn, and A.A. Ross, Handbook of biometrics. 2008: Springer.

[11] Chollet, G., B. Dorizzi, and D. Petrovska-Delacretaz, Introduction - About the Need of an Evaluation Framework in Biometrics, in Guide to Biometric Reference Systems and Performance Evaluation. 2009, Springer. p. 1-10.

[12] Saraswat, C. and A. Kumar, An efficient automatic attendance system using fingerprint verification technique. International Journal on Computer Science and Engineering (IJCSE), 2010. 2(2): p. 264-269.

[13] Shoewu, O. and O.A. Idowu, Development of Attendance Management System using Biometrics. The Pacific Journal of Science and Technology, 2012. 13(1).

[14] El-Abed, M., et al. A study of users' acceptance and satisfaction of biometric systems. in Security Technology (ICCST), 2010 IEEE International Carnahan Conference on. 2010. IEEE.

[15] Tassabehji, R. and M.A. Kamala. Improving e-banking security with biometrics: modelling user attitudes and acceptance. in New Technologies, Mobility and Security (NTMS), 2009 3rd International Conference on. 2009. IEEE.

[16] Kant, C. and R. Nath, Reducing process-time for fingerprint identification system. International Journals of Biometric and Bioinformatics, 2009. 3(1): p. 1-9.

[17] Abdelbary, A.M., Exploration of factors affecting adoption of biometric technology by five-star Egyptian hotel employees. 2011.

[18] Patel, H. and P. Asrodia, Employee Attendance Management System Using Fingerprint Recognition. 2012.

[19] Bhargava, N., et al., Fingerprint Matching using RidgeEnd and Bifurcation Points. 2012.

[20] Kumar, S., et al., Fingerprint Verification based on Fusion of Minutiae and Ridges using Strength Factors.
International Journal of Computer Applications, 2010. $4(1)$.

[21] Babatunde, I.G., A.O. Charles, and A. Cleopas, Fingerprint Matching using Neighbourhood Distinctiveness. International Journal of Computer Applications, March, 2013. 66(21).

[22] Kekre, D.H.B., D.T. Sarode, and R. Vig, Fingerprint identification using sectorized cepstrum complex plane. International Journal of Computer Applications, 2010. 8(1): p. 12-15.

[23] Maheswari, S.U. and E. Chandra, An Efficient Fingerprint Denoiser for Fingerprint Recognition. International Journal of Computer Applications, 2013. 66(22).

[24] Jitendra, C., S. Sharma, and J.S. Verma, A New Framework for improving low Quality Fingerprint Images. International Journal, 2011. 2(6).

[25] Manivannan, N., et al., Fingerprint Biometric for Identity management. International Journal of Industrial Engineering and Management, 2011. 2(2): p. 39-44.

[26] Katiran, N., et al. Development of attendance system using biometric fingerprint identification. in $3 \mathrm{rd}$ Engineering Conference on Advancement in Mechanical and Manufacturing for Sustainable Environment April 14-16, 2010, . 2010. Kuching, Sarawak, Malaysia.

[27] Lakshmi, G.P., FINGERPRINT IDENTIFICATION SYSTEM combined with" CRYPTOGRAPHY" for Authentication. International Journal of Engineering Science and Technology, 2010. 2(7): p. 3054-3077.

[28] Rao, S. and K.J. Satoa, An Attendance Monitoring System Using Biometrics Authentication. International Journal, April, 2013. 3(4).

[29] Oloyede Muhtahir, O., O. Adedoyin Adeyinka, and S. Adewole Kayode, Fingerprint Biometric Authentication for Enhancing Staff Attendance System. system, February, 2013. 5(3).

[30] Agarwal, R. and J. Prasad, Are Individual Differences German to the Acceptance of new Information Technologies. Decision Sciences, 1999. 30(2): p. 361391.

[31] Dishawa, M.T. and D.M. Strong, Extending the technology acceptance model with task technology constructs. Information \& Management, 1999. 36(1999): p. 9-21.

[32] Lederer, A.L., et al., The technology acceptance model and the World Wide Web. Decision Support Systems, 2000. 29(2000): p. 269-282.

[33] Gefen, D. and D.W. Straub, Gender Difference in the Perception and Use of E-Mail: An Extension to the Technology Acceptance Model. MIS Quarterly, 1997. 21(4): p. 389-400.

[34] Igbaria, M., J. Livari, and H. Maragahh, Why do individuals use computer technology? A Finnish case study. Information \& Management, 1995. 29: p. 227-238. 